\title{
Investigation of relationship between attitude to physical education course and school belonging
}

\author{
Uğraş S. ${ }^{\mathrm{ABCDE}}$, Özen G. ${ }^{\mathrm{ABCDE}}$ \\ Department of Physical Education and Sports Teaching, Faculty of Sport Sciences, Çanakkale Onsekiz Mart \\ University, Turkey
}

Authors' Contribution: A - Study design; B - Data collection; C - Statistical analysis; D - Manuscript Preparation; E - Funds Collection.

\begin{abstract}
Purpose:

The purpose of this study was to investigate whether there is a relationship between students' attitudes towards physical education course and belonging to school.

Material:

Research group comprised of 589 (51.5\%) males and 555 (48.5\%) female students in secondary schools of Malatya province. 250 (21.9\%) of the students were 5th grade, $219(19.1 \%)$ were 6 th grade, $387(33.8 \%)$ were 7th grade and 288 (25\%) 2) 8th grade students. School Belonging Scale and Attitude scale to Physical Education course were used as a quantitative data collection tool. Pearson correlation test, simple and multiple regression analyses were used to statistical analysis. Significance level was accepted as $p<.05$.

Results: $\quad$ It was found that there were significant positive correlations in the all sub-domains of attitude and school belonging dimensions to physical education course $(p<.05)$. Regression analyses revealed that the attitudes of students to physical education course predicted school belonging by $11 \%$ and students' attitudes towards physical education course predicted school belonging by $10 \%(p<.05)$.

Conclusions: $\quad$ As a result, students' attitudes towards physical education course increase, their belonging to school increases. In order to increase students' attitudes towards physical education course, it is possible to plan the content and structure of the course in a more fun way.

Keywords: attitude, belonging, physical education, school.
\end{abstract}

\section{Introduction}

It is known that feeling belonging to a certain group, family, community and school has a positive effect on the physical and mental well-being of the individual [1, 2]. Belonging to school is defined as a psychological structure supported by feelings such as attachment to the school, feeling valuable and being accepted by peers [3]. One of the most accepted definitions of school belonging in the literature is defined as a feeling about how much the student is accepted, approved and respected by other individuals [4]. Schools are one of the important opportunities for the individual in the formation of social relations and sense of belonging. Schools are the place where students can interact with their environment outside the family. The student's self-perception of being a part of the school, being happy at school, relations with friends and having a fair environment provide a sense of belonging [5, 6]. In this sense, one of the most important factors affecting school belonging is the school environment [7,8]. The friends, teachers, and other staff members of the student who interact with the school environment are the factors that affect positively or negatively the school belonging. Positive relationships that the student encounters in the school environment will increase his / her belonging while negative situations will decrease his / her belonging. Low or good student loyalty; the acceptance of the student among his friends has a direct effect on the level of happiness, satisfaction, anxiety, feeling of rejection [9].

The adequacy of recreation areas in the school environment, the size of the school, the climate in the classroom, play and socialization are the most influential

(c) Uğraş S., Özen G., 2020

doi:10.15561/18189172.2020.0108 factors affecting belonging $[10,11]$. These factors need to be taken into consideration when arranging the structure of schools. Control and dominance in very large schools will be difficult, as well as problems that may occur in the school environment. The problems that the students may experience in the school environment will negatively affect their belonging. Positive relations with friends $[12,13]$ and teachers $[14,15]$ in the school environment will increase the loyalty of the student. It is stated that the academic success of the students connected to the school is increasing and that these students can avoid the inconvenient situations that they may face [16]. There are many studies examining the relationship between school belonging and academic achievement [17-20]. In these studies, it is observed that academic achievement increases as school belonging increases. Indeed, according to reports [21], students' sense of belonging to the school itself in Turkey was $61 \%$ while the average of the OECD countries is $73 \%$. Turkey is located in the last row of school belonging. In the same report, it was determined that the academic achievement ranking was the 50th among 72 countries.

Physical education course not only contributes to the physical development of students, but also helps to increase self-confidence while reducing stress and anxiety [22]. Physical education and sports contribute to the socialization of the individual with the confidence of the group [23]. Due to its structure, physical education course includes many activities in which students interact with each other. These activities pave the way for the students to have fun with each other and to get together. It is known that physical activity activities have positive effects on the development of peer relationships. Physical 
activity and motivation to do physical activity provide strengthening of social structures such as enjoyable time among peers, group harmony and trust [24-26]. It is a physical education course in the best environment where peer relations can be good. In the researches, it was stated that physical education course was very much liked by the students [27, 28]. Naml, Temel and Güllü [29] found that the metaphors produced by the students against the physical education course included "cheerful" expression. It is seen that students have a positive attitude towards the course in the studies in which attitude to physical education course is examined [27, 30-32]. However, some studies have found that students are negative against physical education courses [33].

When the literature was examined, no direct research examining the attitude and school belonging to physical education course was found. However, there are studies about sports and extracurricular activities. Arıkan [34] examined the feelings of belonging to the school and the quality of life of the students attending the Sports high school and the students of the Anatolian high school. It was determined that the students belonging to the sports high school had higher school belonging and quality of life compared to the students attending the Anatolian high school. The reason for this is that the students who do sports perceive the quality of school life better and therefore they feel a higher belonging to their schools. Yanık [35] found that students who do not do sports have the lowest level of school commitment compared to students who do sports. Extracurricular activities and school belonging studies have shown a positive relationship between them [3638]. In addition to having fun and good time in physical education, it is thought to have a relationship with school belonging in terms of creating a suitable environment for socializing. In this context, it is aimed to investigate whether there is a relationship between students' attitudes towards physical education course and belonging to school.

\section{Material and Methods}

In order to investigate the relationship between secondary school students' attitudes towards physical education course and their belonging to school, relational screening method was used in quantitative research methods. The aim of relational screening studies is to give an idea about the relationship between variables and cause - effect probability between variables [39].

Research Group

589 (51.5\%) males and 555 (48.5\%) female students in secondary schools of Malatya province participated in the study. 250 (21.9\%) of the students were 5 th grade, 219 $(19.1 \%)$ were 6 th grade, $387(33.8 \%)$ were 7 th grade and $288(25 \%)$ 2) 8th grade students.

Data Collection Tools

School Belonging Scale: The original scale was adapted to Turkish culture developed by Goodenow [4] and used "School Belonging Scale", conducted by Sar1 [40]. In the scale, students' sense of appreciation, acceptance and participation in school environment; items were prepared in order to measure their connections with teachers, schools and friends. The scale consisted of a total of 18 items; 13 items in the school attachment dimension and 5 items in the rejected dimension. The scale is in a 5-point Likert scale. "1. Not true at all", "2. Not true", "3. I'm undecided", "4. Correct" and "5. Completely correct". Since the items which are 3rd, 6th, 9 th, 12th and 16th in the scale were negative expressions, scoring was performed by reversing. Cronbach's alpha reliability coefficient was found to be 0.87 in the school commitment dimension, 0.86 in the rejection dimension and 0.85 in the total scale.

Attitude scale to Physical Education course: The scale adapted to Turkish culture by Varol, Ünlü, Erbaş and Sünbül [41] developed by Phillips and Silverman [42] was used. The scale consists of 15 items consisting of two dimensions as cognitive and affective attitude. 4 items in the cognitive dimension and 3 items in the affective dimension contain negative expression. These items are reverse coded. The rating items were coded as "1-Strongly Disagree", "2-Disagree", "3-Undecided", "4-Agree", "5-Strongly Agree". Cronbach's alpha reliability coefficient was found to be 0.83 in cognitive dimension, 0.84 in affective dimension and 0.81 in total scale.

\section{Statistical Analysis}

After the research data were collected, it was found that the skewness and kurtosis coefficients were checked and distributed normally. The skewness values of the variables were found to be between -0.59 and -0.77 , while the kurtosis values ranged between -0.08 and 0.43 . According to Tabachnick and Fidell [43] skewness and kurtosis values between +1.5 and -1.5 is an indicator for the use of parametric tests in the analysis of data. Cronbach's alpha coefficient was examined for reliability of the study. After, Pearson correlation test was used to examine the relationship between the variables. After correlation analysis, simple and multiple regression analyses were used. In simple regression, the independent variable was taken as the attitude to physical education course and the independent variable was taken as belonging to the school. In multiple regression, independent variables were cognitive and affective attitudes, while sub-dimensions of belongingness as school dependent variables were taken to school attachment and rejection dimensions.

\section{Results}

According to the results of the correlation analysis, between cognitive attitude and school commitment $(r=$ $.319, \mathrm{p}<.01$ ), between cognitive attitude and rejection dimension $(\mathrm{r}=.318, \mathrm{p}<.01)$, and between cognitive attitude and school belonging $(r=.373, p<.01)$ positive correlation was found. Between affective attitude and school commitment $(\mathrm{r}=.319, \mathrm{p}<.01)$, between affective attitude and rejection dimension $(\mathrm{r}=.306, \mathrm{p}<.01)$, and between affective attitude and school belonging $(\mathrm{r}=.365$, $\mathrm{p}<.01)$ positive correlation was found. The relationship between attitudes to physical education course and school belonging $(\mathrm{r}=.388, \mathrm{p}<.01)$ was found to be positively 
significant.

When Table 3 is examined, it is seen that attitudes towards physical education course significantly predict school belonging $\left(r=.388, r^{2}=0.15=f=202.025, p\right.$ $<.05)$. It was found that the attitudes of students to physical education course predicted school belonging by $15 \%$.

When Table 4 is examined, it is seen that attitude subdimensions to physical education course significantly predict school commitment $(\mathrm{r}=.335, \mathrm{r} 2=0.11, \mathrm{f}=71.963$, $\mathrm{p}<.05$ ). It was found that the attitudes of students to physical education course predicted school belonging by $11 \%$.

When Table 5 is examined, it is seen that attitude subdimensions to physical education course significantly predict the rejection dimension $\left(r=.329, \mathrm{r}^{2}=0.106, \mathrm{f}=\right.$
$69.079, \mathrm{p}<.05)$. It was determined that students' attitudes towards physical education course predicted school belonging by $10 \%$.

\section{Discussion}

According to the results of the study, it was found that the attitudes of the students in secondary education predicted school belonging by $15 \%$. In this sense, it can be stated that increasing attitude towards physical education course increases student belonging to school. Similarly, it was found that the cognitive and affective dimensions of the physical education lesson attitude scale significantly predicted school commitment and rejection subscales. When the researches are examined, it is a known fact that the attitudes of students to physical education course have

Table 1. Descriptive statistics of attitude and school belonging dimensions to physical education course

\begin{tabular}{llllll}
\hline Variables & $\mathbf{n}$ & $\mathbf{x}$ & ss & skewness & kurtosis \\
\hline School Commitment & 1144 & 3.5169 & .77693 & -.644 & .435 \\
Rejection & 1144 & 3.6848 & .86125 & -.611 & .010 \\
Belonging to the School & 1144 & 3.6008 & .69993 & -.590 & .171 \\
Cognitive Attitude & 1144 & 3.8576 & 1.04976 & -.748 & -.201 \\
Affective Attitude & 1144 & 3.9481 & .97342 & -.859 & .110 \\
Attitude & 1144 & 3.9028 & .96335 & -.770 & -.081 \\
\hline
\end{tabular}

Table 2. Results of correlation analysis of attitude and school belonging dimensions to physical education course

\begin{tabular}{|c|c|c|c|c|c|c|}
\hline Variables & 1 & 2 & 3 & 4 & 5 & 6 \\
\hline 1. School Commitment & 1 & & & & & \\
\hline 2. Rejection & $.459^{* *}$ & 1 & & & & \\
\hline 3. Belonging to the School & $.837^{* *}$ & $.870^{* *}$ & 1 & & & \\
\hline 4. Cognitive Attitude & $.319^{* *}$ & $.318^{* *}$ & $.373^{* *}$ & 1 & & \\
\hline 5. Affective Attitude & $.319^{* *}$ & $.306^{* *}$ & $.365^{* *}$ & $.814^{* *}$ & 1 & \\
\hline 6. Attitude General & $.335^{* *}$ & $.328^{* *}$ & $.388^{* *}$ & $.956^{* *}$ & $.948^{* *}$ & 1 \\
\hline
\end{tabular}

${ }^{*} p<.05 .{ }^{* *} p<.01 .{ }^{* * *} p<.001$

Table 3. Simple regression analysis results of attitude towards physical education course

\begin{tabular}{|c|c|c|c|c|c|}
\hline Variables & B & Standard Error & $\beta$ & $\mathbf{t}$ & $\mathbf{p}$ \\
\hline Constant & 2.501 & 0.080 & - & 31.398 & $0.000 *$ \\
\hline Attitude General & 0.282 & 0.020 & 0.388 & 14.214 & $0.000 *$ \\
\hline$r=0.388^{a} \quad r^{2}=0.15$ & $f=202.025$ & $p=0.000$ & & & \\
\hline
\end{tabular}

$*_{p}<0.01$

Table 4. Results of multiple regression analysis of attitude to physical education course in predicting school commitment dimension

\begin{tabular}{llllll}
\hline Variables & B & Standard Error & $\boldsymbol{\beta}$ & $\mathbf{t}$ & $\mathbf{p}$ \\
\hline \multicolumn{1}{c}{ Constant } & 2.461 & 0.092 & - & 26.868 & $0.000^{*}$ \\
Cognitive Attitude & 0.130 & 0.036 & 0.176 & 3.664 & $0.000^{*}$ \\
Affective Attitude & 0.140 & 0.038 & 0.176 & 3,663 & $0.000^{*}$ \\
$\mathrm{R}=, 335^{\mathrm{a}} \quad \mathrm{R}^{2}=0.11$ & $\mathrm{~F}=71.963$ & $\mathrm{P}=0.000$ & & & \\
\hline
\end{tabular}

* $p<0.01$ 
Table 5. Results of multiple regression analysis of attitude to physical education lesson predicting rejection dimension

\begin{tabular}{llllll}
\hline Variables & B & Standard Error & $\boldsymbol{\beta}$ & $\mathbf{t}$ & $\mathbf{p}$ \\
\hline Constant & 2.548 & 0,102 & - & 25.037 & $0.00^{*}$ \\
Cognitive Attitude & 0.168 & 0.039 & 0.204 & 4.247 & $0.00^{*}$ \\
Affective Attitude & 0.124 & 0.043 & 0.140 & 2.918 & $0.04^{*}$ \\
$\mathrm{R}=0.329 \mathrm{R} \quad \mathrm{R}^{2}=0.106$ & $\mathrm{~F}=69.079$ & $\mathrm{P}=0.000$ & & & \\
\hline
\end{tabular}

$*_{\mathrm{p}}<0.01$

positive attitude [27, 30-32]. The reason why the attitudes of the students to physical education lessons are high can be shown as having good and fun lessons. As a matter of fact, the students defined and perceived the physical education course as cheerful [29] and loved [27, 28] and fun [44]. In this context, it can be said that physical education course may have increased the level of belonging and loyalty of students as it is a fun and good time course. It was stated that the activities including organized activities and sports activities had a positive effect on school belonging [45]. It can be stated that physical education course is a good option in creating the environment that best offers the opportunity to make these activities systematically and programmed. Physical education course has a structure of group cohesion where students can easily communicate with each other [23]. Because the group and team cooperation of the activities carried out allows students to strengthen the communication link with each other. In the literature, it is stated that physical activities lead to strengthening of social structures such as trust and group harmony among peers [24-26]. In this sense, the best course of peer relations is physical education. It has been clearly demonstrated in studies that peer relationships affect school belonging $[12,46]$. It can be stated that physical education course creates an environment that can strengthen peer relations and has an effect on increasing the loyalty of students to school.

Avşar [47] found that physical education teachers had high social skills. The high level of social skills of physical education teachers enables better dialogue with the students. The reasons such as not approaching the students at school based on their academic success and wearing tracksuits with students may make them feel closer to the physical education teacher. It can be said that this affinity to physical education teacher has a positive effect on school belonging. Research has shown that good dialogue with teachers increases school belonging [14, 15, 48]. Arastaman [49] showed that teachers are among the reasons that reduce students' commitment to school. In the researches, it is seen that teacher character plays an important role in decreasing and increasing the students' belonging. Physical education teachers 'ability to establish good dialogue with students, good communication skills and high social skills may have positively affected students' commitment and belonging to school.

\section{Conclusion}

Based on the results of the research, as students' attitudes towards physical education course increase, their belonging to school increases. In order to increase students' attitudes towards physical education course, it is possible to plan the content and structure of the course in a more fun way.

\section{Acknowledgement}

We gratefully acknowledge the help of all the participant who took part in the study.

\section{Conflict of interests}

The authors state that there is no conflict of interest

\section{References}

1. Holt-Lundstadt J, Smith TB, Layton, JB. Social Relationships and Mortality Risk: A Metaanalytic Review. PLoS Med, 2007;7(7): e1000316. https://doi.org/10.1371/journal.pmed.1000316

2. O'Brien KA, Bowles TV. The importance of belonging for adolescents in secondary school settings. The European Journal of Social \& Behavioural Sciences, 2013;5(2):985-976. https://doi.org/10.15405/ejsbs.72

3. Willms JD. Monitoring school performance for 'standards-based reform'. Evaluation \& Research in Education, 2000;14, 237-253. https://doi.org/10.1080/09500790008666976

4. Goodenow C. The psychological sense of school membership among adolescents: Scale development and educational correlates. Psychology in the Schools, 1993;30(1):79-90.
https://doi.org/10.1002/1520-6807(199301)30:1<79::AIDPITS2310300113>3.0.CO;2-X

5. Hurtado S, Carter DF. Effects of college transition and perceptions of the campus racial climate on Latino college students' sense of belonging. Sociology of Education, 1997;70(4):324-345. https://doi.org/10.2307/2673270

6. Libbey HP. School connectedness: Influence above and beyond family connectedness (Doctoral dissertation). Retrieved from ProQuest Dissertations and Theses database (UMI No. 3287822). 2007.

7. Loukas A, Roalson LA, Herrera DE. School connectedness buffers the effects of negative family relations and poor effortful control on early adolescent conduct problems. Journal of Research on Adolescence, 2010;20(1):13-22. https://doi.org/10.1111/j.1532-7795.2009.00632.x 
8. Slaten CD, Ferguson JK., Allen KA, Brodrick DV, Waters L. School belonging: A review of the history, current trends, and future directions. The Educational and Developmental Psychologist, 2016;33(1):1-15. https://doi.org/10.1017/edp.2016.6

9. Osterman FK. Students' need for belonging in the school community. Review of Educational Research. 2000; 70(3);323-367. https://doi.org/10.3102/00346543070003323

10.Anderson A, Hamilton RJ, Hattie J. Class room climate and motivated behaviour in secondary schools. Learning Environments Research. 2004;7(3):211-225. https://doi.org/10.1007/s10984-004-3292-9

11. Waters S, Cross D, Shaw T. Does the nature of schools matter? An exploration of selected school ecology factors onadolescent perceptions of school connectedness. British Journal of Educational Psychology. 2010;80(Pt3):381-402. https://doi.org/10.1348/000709909X484479.

12.Perdue NH, Manzeske DP, Estell, DP. Early predictors of school engagement: Exploring the role of peer relationships. Psychology in the Schools, 2009:46(10);1084- 1097. https://doi.org/10.1002/pits.20446

13.Özgök, A., \& Sarı, M. (2016). Ortaokul öğrencilerin okula aidiyet duygusu ve arkadaş bağlllık düzeyi. [Investigation of the sense of school belongong and peer attachment among secondary school students]. Çukurova Üniversitesi Sosyal Bilimler Enstitüsü Dergisi. 2016;25(3):71-86 (in Turkish)

14.Özdemir S, Sezgin F, Şirin H, Karip E, Erkan S. (2010). İlköğretim okulu öğrencilerinin okul iklimine ilişkin algılarını yordayan değişkenlerin incelenmesi. [Examining the variables predicting primary school students' perceptions of school climate]. Hacettepe Üniversitesi Ĕ̆itim Fakültesi Dergisi. 2010;38;213-224 (in Turkish)

15.Garcia-Reid P. Examining social capital as amechanism for improving school engagement among low income hispanic girls. Youth \& Society. 2007;39(2):164-181. https://doi.org/10.1177/0044118X07303263

16.Skinner E, Furrer C, Marchand G, Kindermann T. Engagement and disaffection in the classroom: Part of a larger motivational dynamic?. Journal of Educational Psychology. 2008;100(4): 765-781. https://doi.org/10.1037/ a0012840

17.Anderman EM. School effects on psychological outcomes during adolescence. Journal of Educational Psychology. 2002; 94(4);795-809. https://doi.org/10.1037//0022-0663.94.4.795

18. Arslan G. Relationship between sense of rejection, academic achievement, academic efficacy, and educational purpose in high school students. Egitim ve Bilim, 2016;41(183);293-304. https://doi.org/10.15390/EB.2016.5562

19.Booker CK. exploring school belonging and academic achievement in African American adolescent. Curriculum and Teaching Dialogue. 2004;6(2):131-143.

20.Pittman L, Richmond A. Academic and psychological functioning in late adolescence: The importance of school belonging. The Journal of Experimental Education. 2007;75(4):270-290. https://doi.org/10.3200/JEXE.75.4.270-292.

21.PISA. Results Students' Well-Being, [Internet]. 2015. [updated 2017 April 19; cited 2019 Oct 15]. Available from: https://doi.org/10.1787/9789264273856-en

22.MorganPJ, Saunders KL, Lubans DR. Improving physical selfperception in adolescent boys from disadvantaged schools: psychological outcomes from the physical activity Leaders randomized controlledtrial.Pediatricobesity, 20127(3),27-32. https://doi.org/10.1111/j.2047-6310.2012.00050.x
23.Aybek A, İmamoğlu O, Taşmektepligil MY. An assessment of the attitudes of students towards physical education lesson and extracurricular activities. Journal of Sports and Performance Researches. 2011;2(2):51-59.

24.Haapala HL, Hirvensalo MH, Laine K, Laakso L, Hakonen H, Kankaanpää A, Taru L, Tammelin TH. Recess physical activity and school-related social factors in Finnish primary and lower secondary schools: Cross-sectional associations. BMC Public Health. 2014;14:Article 1114. https://doi.org/10.1186/1471-2458-14-1114

25.Hairul H, Grove JR, Whipp P. Validating the youth sport enjoymentconstructinhighschoolphysicaleducation. Research Quarterly for Exercise and Sport. 2008;79(2):183-194. https://doi.org/10.1080/02701367.2008.10599482

26.Smith MA, St. Pierre PE. Secondary students' perceptions of enjoyment in physical education: An American and English perspective. The Physical Educator. 2009; 66(4):209-221.

27.Erhan SE, Tamer K. The relation between facilities and equipment for the course of physical education and sports and students' attitudes towards the course primary and secondary schools in Eastern Anatolia. Atatürk Üniversitesi Beden Eğitimi ve Spor Bilimleri Dergisi. 2017:11(3);57- 66.

28. Tannehill D, Zekrajsek D. Student attitudes toward physical education: A multicultural study. Journal of Teaching Physical Education. 1993;13(1);78-84. https://doi.org/10.1123/jtpe.13.1.78

29.Namlı A, Temel C, Güllü M. Metaphors produced by secondary school students related to physical education lesson. Kastamonu Education Journal. 2017;25(2):479-496.

30.Hünük D, Demirhan G. Comparison of primary school, secondary school and university students' attitude toward physical education and sports. Hacettepe J. of Sport Sciences. 2003;14(4);175-184.

31.Kannan B. Attitude of higher secondary students towards physical education. International Journal of Teacher Educational Research. 2015;4(1):19-25.

32.Subramaniam PR, Silverman S. Middle School students' attitudes toward physical education. teaching and teacher education. 2007;2 (5):602-611. https://doi.org/10.1016/j.tate.2007.02.003

33.Gürbüz A, Özkan H. Determining the attitude of secondary school students toward physical education of sport lesson (Muğla sample). Pamukkale Journal of Sport Science. 2012;3(2);78-89.

34.Arıkan G. Examination of Sense of School Belonging in the Students at Sports and Anatolia High Schools: Southeastern Anatolia Region Sample. 5th International Conference on Science Culture and Sport, Türkistan: Kazakistan; 2016. P. 13-15.

35.Yanık, M. (2018).The effects of on the high school students engagement level of sport events spormetre Beden Eğitimi ve Spor Bilimleri Dergisi, 16(1), 73-78. https://doi.org/10.1501/Sporm_0000000344

36.Barber BL, Eccles JS, Stone MR. Whatever happened to the jock, the brain, and the princess? Young adult pathways linked to adolescent activity involvement and social identity. Journal of Adolescent Research. 2001;16(5):429-455. https://doi.org/10.1177/0743558401165002

37.IvaniushinaVA, Aleksandrov DA. Socialization through informal education: The extracurricular activities of Russian school children. Russian Education \& Society. 2015;57(4):189-213. https://doi.org/10.1080/10609393.2015.1068553

38.Y1lmaz A. Investigation of high school students' attitudes towards extracurricular sport activities and their attachment to school. Gaziantep Üniversitesi 
Spor Bilimleri Fakültesi Dergisi. 2019;4(1):50-63. https://doi.org/10.31680/gaunjss.518094

39.Fraenkel JR, Wallen NE, Hyun HH. How to design and evaluate research in education. New York: McGraw-Hill; 2012.

40.Sarı M. Adaptation of the Psychological Sense of School Membership Scale to Turkish. Global Journal of HumanSocial Science: G Linguistics \& Education. 2015;15(7):1521.

41.Kalemoğlu VY, Ünlü H, Erbaş MK., Sünbül AM. Turkish adaptation of the elementary physical education attitude scale. Hacettepe Journal of Sport Sciences. 2016;27(1):1626.

42.Phillips SR, Silverman S. Development of an instrument to assess fourth and fifth grade students' attitudes toward physical education. Measurement in Physical Education and Exercise Science. 2012:16(4);316-327.

43.Tabachnick BG, Fidell LS. Using multivariate statistics (5th ed.). Boston: Allyn and Bacon; 2007.

44.Yılmaz A, Güven Ö. Parents attitude scales toward extracurricular sport activities. Niğde University Journal of Physical Education And Sport Sciences. 2015;9(2):244-258.
45.Fredricks JA, Eccles JS. Extracurricular involvement and adolescent adjustment: Impact of duration, number of activities, and breadth of participation. Applied Developmental Science. 2006;10:132-146. https://doi.org/10.1207/s1532480xads1003_3

46.Isakson K, Jarvis P. The adjustment of adolescents during the transition into high school: A short term longitudinal study. Journal of Youth and Adolescence. 1999; 28(1):1-26. https://doi.org/10.1023/A:1021616407189

47.Avşar Z. Beden eğitimi ve spor öğretmenlerinin sosyal beceri düzeylerinin belirlenmesi. [Determing physical education and sport teachers' social skills who works in state and private schools in Bursa]. Uludağ Üniversitesi Ĕgitim Fakültesi Dergisi. 2014;17(2):111-130. (in Turkish)

48.Brewster AB, Bowen GL. Teacher support and the school engagement of Latino middle and high school students at risk of school failure. Child and Adolescent Social Work Journal. 2004; 21(1):47-67. https://doi.org/10.1023/B:CASW.0000012348.83939.6b

49. Arastaman G. Students', teachers' and administrators' opinions about freshman high school students' engagement. Pamukkale Üniversitesi Ë̆itim Fakültesi Dergisi. 2009;26(26):102-112.

\section{Information about the authors:}

Uğraş S.; http://orcid.org/0000-0001-5756-653X; sinanugras@comu.edu.tr; Department of Physical Education and Sports Teaching, Faculty of Sport Sciences, Çanakkale Onsekiz Mart University; Sports Science Faculty 17000 Çanakkale, Turkey.

Özen G.; (Corresponding author); http://orcid.org/0000-0001-5756-653X; gokmenozen44@gmail.com; Department of Physical Education and Sports Teaching, Faculty of Sport Sciences, Çanakkale Onsekiz Mart University; Sports Science Faculty 17000 Çanakkale, Turkey.

Cite this article as:

Uğraş S, Özen G. Investigation of relationship between attitude to physical education course and school belonging.

Pedagogy of physical culture and sports, 2020;24(1):48-53.

https://doi.org/10.15561/18189172.2020.0108

This is an Open Access article distributed under the terms of the Creative Commons Attribution License, which permits unrestricted use, distribution, and reproduction in any medium, provided the original work is properly cited (http://creativecommons.org/licenses/by/4.0/deed.en).

Received: 10.10 .2019

Accepted: 05.11.2019; Published: 10.11.2019 